\title{
SYNDROME OF CEREBROCORTICAL NECROSIS EXPERIMENTALLY INDUCED IN CALVES BY ADMINISTRATION OF AMPROLIUM
}

\author{
J. BOUDA, P. JAGOS, V. DVOŘ́K, L. PIVNÍK \\ Department of Diagnostics, Therapy and Prevention of Animal Diseases, University of Veterinary \\ Science, 61242 Brno
}

Received Fuly 2, 1981

\begin{abstract}
Bouda J., P. Jagoš, V. Dvořák, L. Pivník: Syndrome of Cerebrocortical Necrosis Experimentally Induced in Calves by Administration of Amprolium. Acta vet. Brno, 50,1981 : 109-116

In the experiment into which three experimental and four control calves were included the syndrome of cerebrocortical necrosis (CCN) was induced by the administration of Amprolium. Pathogenesis and symptomatology of the condition were followed. After the intraruminal administration of Amprolium $(0.5 \mathrm{~g} / \mathrm{calf} / \mathrm{day})$ the clinical signs appeared in two calves after six weeks while in the third calf after 56 days. The main clinical features were: inappetence, blindness, increased excitability, symptoms of static and kinetic ataxia. Calves rose with difficulties, had difficulty avoiding objects, muscular tremor and opisthotonus appeared, when falling tonic-clonic convulsions and paddling movements were observed. The observed clinical signs were identical with those of spontaneous cases of CCN in calves.

Statistically significant decrease of thiamine content was determined in cerebral cortex, cardiac and skeletal muscle of experimental calves. In liver tissue there was no significant decrease of thiamine level. Fourteen days after the administration of Amprolium the erythrocyte transketolase activity was found to decrease while the thiamine pyrophosphate effect in blood increased. Pathologico-anatomical examination of brain revealed cerebral oedema and yellow coloured foci on some gyri. Histopathological changes in these parts were characterized by necrosis of the grey matter and enormous infiltration of macrophages. However, when comparing the plasma levels of vitamin $\mathrm{A}, \mathrm{E}$ and $\mathrm{C}$, minerals, $\mathrm{Na}, \mathrm{K}, \mathrm{Ca}, \mathrm{Mg}$, inorganic $\mathrm{P}, \mathrm{Zn}, \mathrm{Cu}$, or urea, glucose, asparateaminotransferase and gamma glutamyl transferase activity, acid-base balance in the blood and of some parameters in the rumen fluid, no significant differences were found between experimental and control groups.
\end{abstract}

Calf, plasma, hypovitaminosis $B_{1}$, transketolase, TPP effect, vitamins $A, E, C$, minerals $\mathrm{Na}, \mathrm{K}, \mathrm{Mg}, \mathrm{Ca}$, inorg. $\mathrm{P}, \mathrm{Zn}$, and $\mathrm{Cu}$, urea, glucose, acid-base balance, rumen fluid.

On the basis of knowledge obtained in traditional forms of husbandry it was assumed that the vitamin $B_{1}$ requirement in ruminants was fully covered by microbial synthesis in forestomachs. Changes in husbandry practices particularly in feeding and dietetic practices, have corrected some of the common opinions concerning above all the rearing of calves and young cattle, including beef cattle. Calves in their first weeks of life are entirely dependent on thiamine supply from feed (Draper, Johnson 1951; Benevenga et al. 1964). Milk and colostrum contain large quantities of thiamine. Cow colostrum contains $60 \mathrm{mg} / \mathrm{l}$, milk $30 \mathrm{mg} / \mathrm{l}$ (Zintzen 1973). It is apparent from

Preliminary results presented at the Scientific Conference with international participation at the University of Veterinary Medicine, held in Brno, on June 5th, 1980. 
literature data that the thiamine requirement in ruminants is dependent on animal age, feeding, quality and type of diet and on other factors as housing, infection or parasitic invasion.

The thiamine deficiency is caused by its insufficient dietary supply or by the action of a thiamine antagonist. Thiamine antagonists occur in various plants, bacteria and fungi. They can change the chemical structure of vitamin $\mathbf{B}_{1}$, or their own chemical structure closely resembles that of thiamine. The action of these antagonists in enzyme systems in caused by the mechanism of competitive inhibition. The significant role in the incidence of hypovitaminosis $B_{1}$ in ruminants is ascribed to thiaminases which decompose vitamin $B_{1}$ (Shreeve, Edwin 1974; Morgan, Lawson 1974).

One of the causes of the cerebrocortical necrosis (CCN) syndrome could be due to the decreased synthesis of vitamin $B_{1}$ in the rumen occurring in digestive disturbances in forestomachs. The syndrome of cerebrocortical necrosis is often linked with rumen acidosis (Flachowsky et al. 1974; Jagoš et al. 1979).

The CCN syndrome can be induced experimentally by thiamine antagonists, such as pyrithiamine, oxythiamine and amprolium Out of these the most suitable preparation for the experiments seems to be a coccidiostat Amprolium (Pill et al. 1966; Little 1969; Espinasse et al. 1971; Loew, Dunlop 1972; Lilja 1973; Markson et al. 1972, 1974).

A sporadic occurrence of CNS disease in calves and young cattle with clinical symptoms resembling those of CCN has already been observed in various parts of Czechoslovakia. In recent years this syndrome has been appearing more frequently, particularly in older calves (Jagoš et al. 1981). The purpose of the present work was to study the manifestation of hypovitaminosis $B_{1}$ in calves. Our attention was focused at a deeper elucidation of the genesis of this disease, at clinical, biochemical and pathologico-morphological symptoms of experimentally induced CCN syndrom as well as at the elaboration of objective diagnostic methods in relation to a spontaneous incidence of this. disease.

\section{Materials and Methods}

Seven calves of the Bohemian Pied Breed were included in the experiment. Three experimental calves were 3 months old, their mean body mass at the beginning of the experiment being $97 \mathrm{~kg}$. The control group consisted of four calves with mean body mass of $95 \mathrm{~kg}$. Prior to the Amprolium administration the experimental and control calves underwent a three week adaptation period during which the animals were changed to a defined type of feed ration. The diet consisted of granulated feeds, alfalfa hay, straw and water. The CCN syndrome was induced by the daily administration of Amprolium ( $0.5 \mathrm{~g} / \mathrm{kg}$, later $0.75 \mathrm{~g} / \mathrm{kg}$ of body mass). The total time period of the administration of Amprolium was 42-54 days.

The clinical examination of calves was carried out daily and included the determination of respiratory and pulse rate, temperature, the examination of alimentary tract, respiratory, cardiovascular, musculoskeletal and nervous systems. When first signs appeared, reflexes, cutaneous and subcutaneous perceptivity and musculoskeletal systems were examined twice a day. Daily body mass gains amounting to $0.61 \mathrm{~kg} /$ head and $0.75 \mathrm{~kg} / \mathrm{head}$ of experimental and control group, resp., were followed.

Blood samples were collected from v. jugularis. During the experiment the rumen fluid was taken six times using a stomach tube. Samples of blood, rumen fluid and urine both from experimental and control animals were collected after killing. From each calf three samples of cerebral cortex, a sample of cardiac muscle from the left ventricle, of liver, and of striated muscle (m. gracilis) were taken.

Thiamine level in tissues was determined by the method of Picková (1969). Transketolase (TK) activity and thiamine pyrophosphate (TPP) effect were measured by a modified method by Brin (1974). The determination of vitamin $\mathbf{A}$ and $\mathbf{E}$ in blood plasma was carried out using a PerkinElmer 204 spectrofluorometer, by the method of Thom son et al. $(1971,1973)$ as modified by Jagoš et al. (1978). Concentration of vitamin C was assayed by a method described by Bessey et al. (1947).

Acid-base balance of venous blood was determined by the Astrup method on a Blood Micro. Equipment(BME 22) Radiometer using the Siggaard-Andersen nomogram. Hematocrit was determined by a routine micromethod in capillaries, hemoglobin and leucocyte count using the Coul-. ter Counter. Concentrations of $\mathrm{Na}, \mathrm{K}, \mathrm{Ca}, \mathbf{M g}, \mathrm{P}, \mathrm{Cu}$ and $\mathrm{Zn}$ in blood plasma were determined by atomic absorption spectrophotometry. Inorganic phosphorus, aspartate aminotransferase (AST). and gamma glutamyl transferase (GMT) activites, levels of glucose and urea in blood plasma were obtained using the Bio-tests (Lachema Brno). In rumen fluid the determination of $\mathrm{pH}$, acetic, propionic and butyric acids were carried out by gas chromatography. 


\section{Results}

The food consumption of the Amprolium-treated calves was normal until the development of clinical signs. Four to five weeks after the administration of Amprolium bristled hair on head and back of the experimental animals were noted. Body temperature, heart and respiratory rates were normal. After six weeks following the administration a slight inappetence, increased excitability, gradual blindness, symptoms of static and kinetic ataxia appeared. Calves rose with effort, had difficulty avoiding objects, muscle tremor, opisthotonus and when falling tonic-clonic convulsions developed. Convulsions were accompanied by accelerated respiratory and higher pulse rate, general weakness and recumbency. In recumbent calves tonic-clonic convulsios lasting 1-3 minutes and paddling were also observed. It was possible to induce tonic-clonic convulsions by sound and light stimuli. On both hind limbs and on fore limbs distally from carpus the cutaneous sensitivity disappeared. In recumbent animals marked disturbances of digestive system characterized by inappetence, tympany and diarrhoea were found. As for the third calf the same clinical signs were manifested 54 days after the administration of Amprolium.

In order to find objectively the primary pathologicomorphological changes on CNS the calves were slaughtered 1-2 days after becoming recumbent. Pathologico-anatomical as well as histological examination revealed yellow discoloration of some cortical gyri. Histological changes in these parts were characterized by necrosis of the grey matter and infiltration of macrophages.

The thiamine content in cerebral cortex and skeletal muscle of the experimental group was found to be significantly lower $(P<0,01)$ when compared with the control group. Statistically significant decrease $(P<0.05)$ of thiamine content was determined also in heart muscle (Fig. 1). A decreased thiamine content was found even in liver tissue of experimental animals but this was, however, not of statistical significance in comparison with the controls. Erythrocyte transketolase (TK) activity and thiamine pyrophosphate (TPP) effect of experimental and control calves during

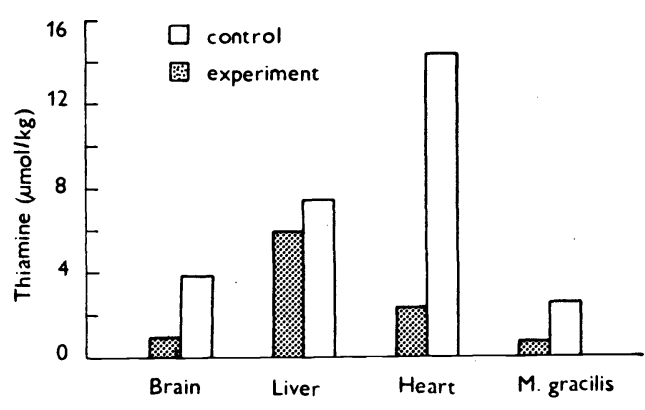

Fig. 1

Thiamine content in brain liver, heart and skeletal muscle of experimental (Amprolium-treated) and control group of calves

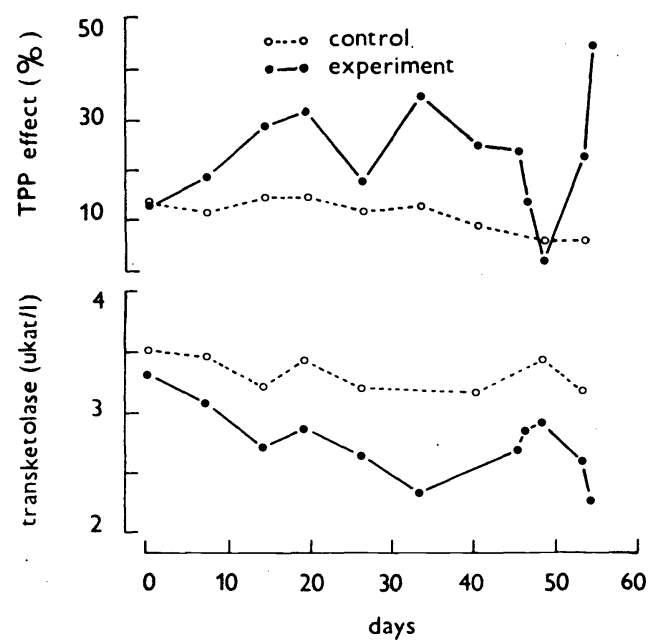

Fig. 2

Thiamine pyrophosphate effect and erythrocyte transketolase activity of calves 


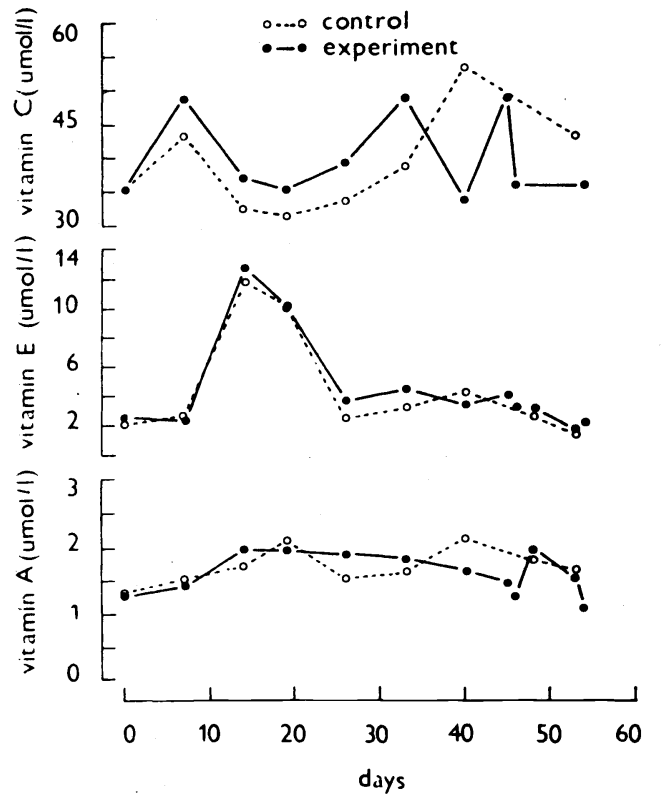

Fig. 3

Vitamin A, E and C levels in blood plasma of calves

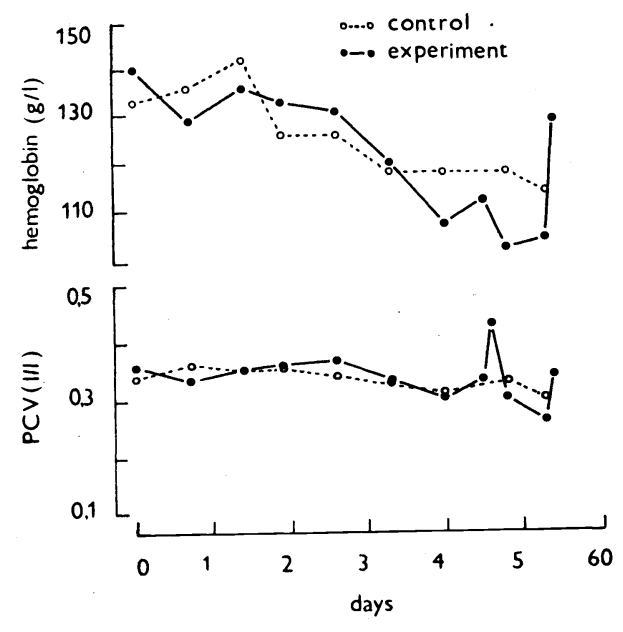

Fig. 5

Hemoglobin concentration and PCV values in blood of calves

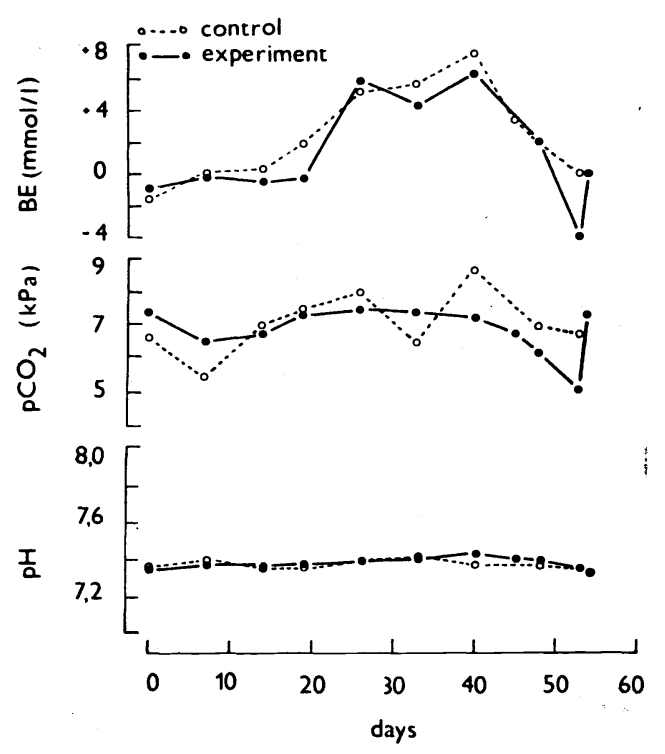

Fig. 4

$\mathrm{pH}$, base ecess, $\mathrm{pCO}_{2}$ in blood of calves

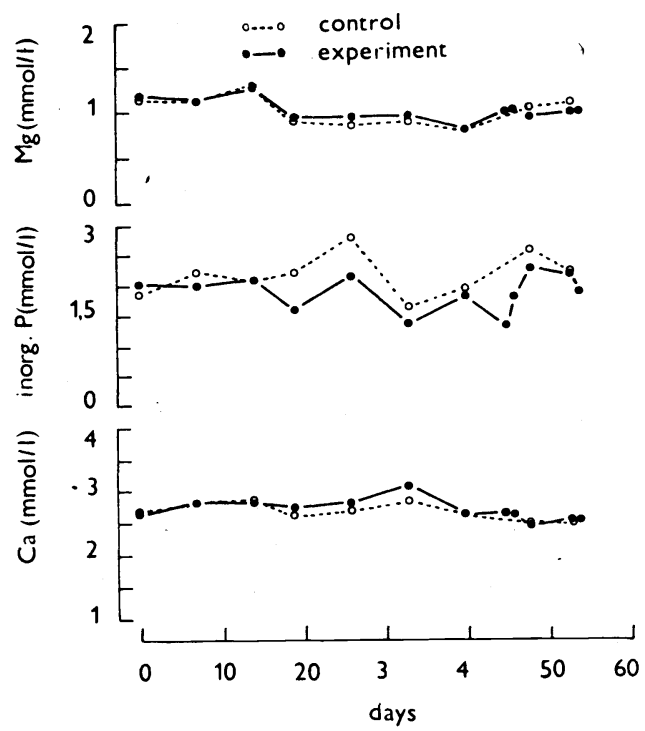

Fig. 6

$\mathrm{Ca}$, inorganic $\mathbf{P}$ and $\mathbf{M g}$ levels in blood plasma of calves 
the comparable period statistically significantly different already one month after the Amprolium administration (Fig. 2) As for control animals the transketolase activity and TPP effect were found to be lower.

The results of vitamin $\mathrm{A}, \mathrm{E}$ and $\mathrm{C}$ determination in blood plasma of calves are presented in Fig. 3. During the experiment a significant increase in vitamin A and E concentrations in blood plasma of the experimental group was observed only once.

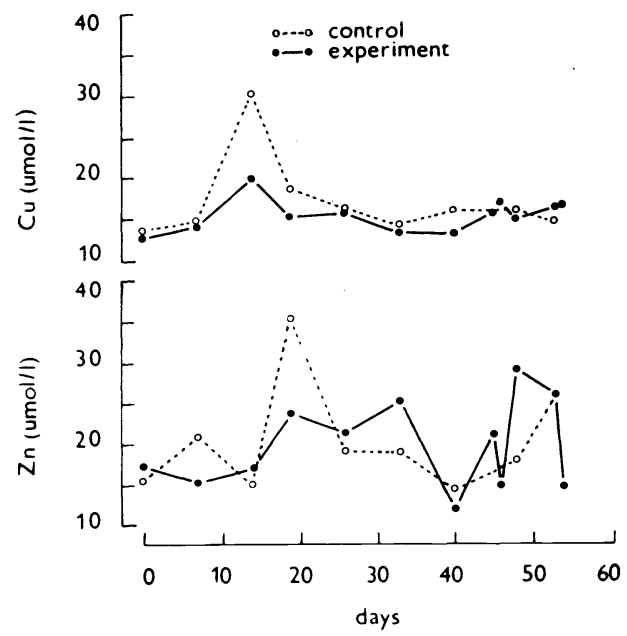

Fig. 7

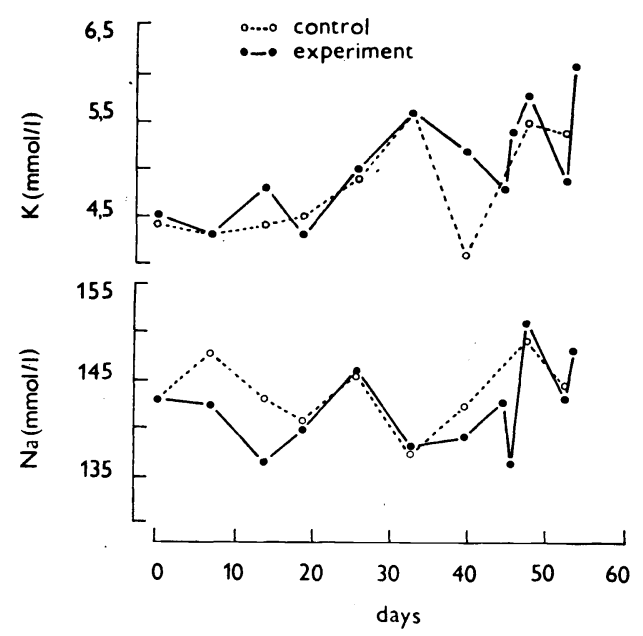

Fig. 8

$\mathrm{Zn}$ and $\mathrm{Cu}$ levels in blood plasma of calves

Fig. 4 shows the dynamics of acid-base balance changes in the blood of calves. In the course of the experiment non-significant differences were found between both groups of calves. At the beginning a tendency to a slight acidosis was established in the blood od both groups, later the base-excess (BE) values increased to alkalic range which indicated the development of alkalosis. BE values dropped however again after the manifestation of clinical signs. As for PCV and hemoglobin values in blood (Fig. 5), plasma concentrations of $\mathrm{Ca}$, inorganic $\mathrm{P}, \mathrm{Mg}$ (Fig. 6), $\mathrm{Zn}$ and $\mathrm{Cu}$ (Fig. 7), $\mathrm{Na}$ and $\mathrm{K}$ (Fig. 8), urea, glucose and total protein (Fig. 9) no significant differences were found between both groups od calves. Between AST and GMT activities in blood plasma of experimental and control groups repeatedly no significant differences were established, the exception being the increase of AST activity (Fig. 10) in recumbent calves of the experimental group. One month after the onset of the experiment significant lower content of acetic acid and total content of volatile fatty acids in "rumen" fluis was observed in one case in the experimental group, the content of butyric acid being, however, increased.

\section{Discussion}

Amprolium, one of the thiamine antagonists which can induce the thiamin deficiency, was used in our experiment, the reason being that according to Markson (1972) the histopathological changes induced by the administration of this antimetabolite in central nervous system of young calves resemble very much the changes developed in spontaneous cerebrocortical necrosis. The origin of these changes could be explained by the action of Amprolium that blocks the ac- 


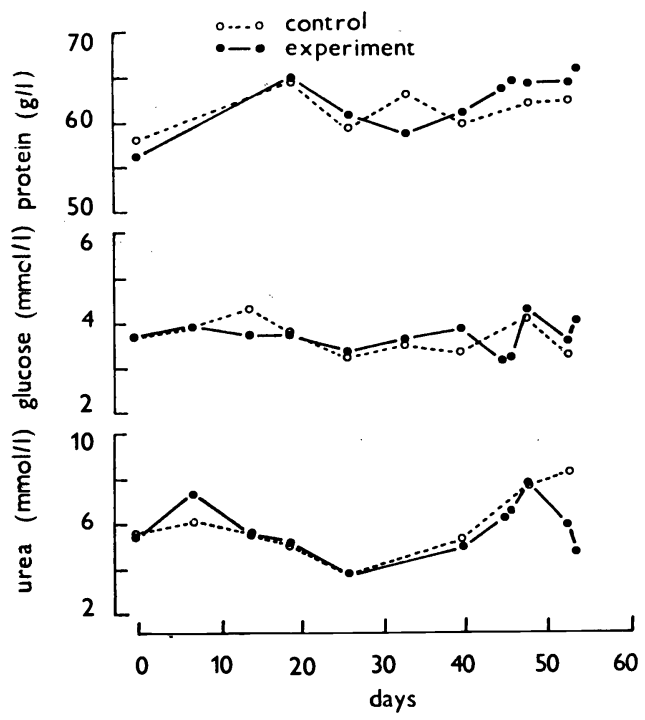

Fig. 9

Urea, glucose and protein concentrations in blood plasma of calves

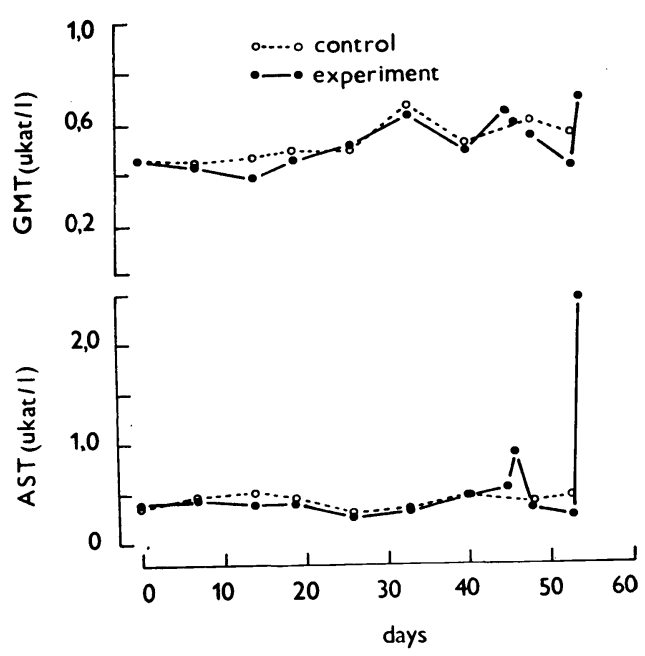

Fig. 10

Aspartate aminotransferase and gamma glutamyltransferase activity in blood plasma of calves

tive transport of thiamine, probably by competition on membranes (Sharma and Quastel 1965).

Clinical signs experimentally produced in calves by the administration of Amprolium were very similar to those of spontaneously diseased calves with $\mathrm{CCN}$. At present the knowledge of ethiopathogenesis of $\mathrm{CCN}$ is not complete and a more detailed research into this problem is needed, particularly in the field concerning the interactions of metabolites.

The results of laboratory analyses of cases with CCN syndrom have shown that the determination of thiamine content in tissues and erythrocyte transketolase activity is the most important from the point of view of diagnostics and differencial diagnostics. In experimentally induced CCN syndrome by the Amprolium administration the most significant decrease of thiamine content was found in brain tissue, the value falling by $75 \%$ in average. A pronounced decrease of thiamine content was observed also in muscles. The lowered thiamine content in liver of calves following the administration of Amprolium was found to be insignificant. In contrast to these findings a highly significant fall of thiamine content in liver occurs in spontaneous CCN in calves (Edwin et al. 1979; Jagoš et al. 1981).

The values of TPP effect are indirectly indicative of the saturation of organism with thiamine. Already 14 days after the administration of Amprolium the TK activity decreased while the TPP effect was found to increase in calves with the experimentally induced CCN. The increase of the TPP effect observed by us was always substantially lower than the values reported by Edwin et al. (1979). When studying the dynamics of plasma levels of vitamin $\mathrm{A}, \mathrm{E}$ and $\mathrm{C}$, of minerals $\mathrm{Na}$, $\mathrm{K}, \mathrm{Ca}, \mathrm{Mg}$, inorganic $\mathrm{P}, \mathrm{Zn}$, and $\mathrm{Cu}$, of urea, glucose, aspartate aminotransferase and gamma glutamyl transferase activity, blood acid-base balance and of some other parameters in rumen fluid no significant differences were found between the ex- 
perimental and control group. Normal serum levels of $\mathrm{Ca}, \mathrm{Mg}, \mathrm{Na}$ and $\mathrm{K}$ in Amprolium-treated calves stated also Lilja (1973) whereas Markson et al. (1966) found decreased plasma levels of potassium.

It follows from our studies of cerebrocortical necrosis and of experimentally induced CCN syndrom that for establishing an objective diagnosis of CCN the knowledge of reliable history together with a repeated clinical examination are essential. The pathologico-morphological findings in the cerebral cortex ( $T$ erlecki, Markson 1961; Pivník 1972) and the determination of the lower thiamine content in liver, brain and muscle tissue (Jagoš et al. 1981) have the decisive significance for the confirmation of diagnosis as well as for the differential diagnosis. The preclinical stage of $\mathrm{CCN}$ could be diagnosed on the basis of the incidence of lower TK activity in blood and of increased TPP effect. The improvement in the condition of affected calves following the administration of thiamine could be used for indirect diagnosis.

It follows from the results obtained by the studies of symptoms in Amprolium -treated calves that the development of the experimentally induced disease somewhat differs from the spontaneously occurring $\mathrm{CCN}$ syndrome. It can be concluded that the CCN syndrome experimentally induced by the administration of Amprolium is not a suitable model for the study of the pathogenesis and symptomatology of spontaneously developed CCN in calves.

\section{Syndrom cerebrokortikální nekrózy experimentálně vyvolaný aplikací amprolia u telat}

V experimentu, na 3 pokusných a 4 kontrolních telatech byl aplikací Amprolia vyvolán syndrom cerebrokortikální nekrózy (CCN). Byla sledována patogenéza a symptomatologie vyvolané poruchy. Klinické příznaky se objevily u 2 telat za 6 týdnů po intraruminální aplikaci Amprolia ( $0,5 \mathrm{~g} / \mathrm{tele} / \mathrm{den})$, u třetího telete za 54 dnů. Hlavními klinickými př́iznaky byly inapetence, slepota, zvýšená dráždivost, prýiznaky statické a kinetické ataxie. Telata s obtižemi vstávala, narážela do překážek, objevovaly se svalové třesy, opistotonus, a při upadnutí tonicko-klonické kreče a plovací pohyby. Zjištěné klinické přiznaky byly totožné s projevy spontánního onemocnění telat $\mathrm{CCN}$.

\section{Синдром церебро-кортикального некроза, экспериментально вызванный применением ампролия у телят}

В әксперименте над 3 подопытными и 4 контрольными телятами был вызван применением ампролия синдром цереброкортикального некроза (СЦН). Проводились исследования патогенеза и симптоматологии вызван-ного нарушения. Клинические признаки появились у 2 телят через 6 недель после внутрирубцового введения ампролия (0,5 г/телёнок/сутки), у третьего теленка - через 54 дня. Главные клинические признаки - отсутствие аппетита, слепота, повышенная раздражительность, признаки статической и кинетической атаксии. Телята с трудом поднимались, неталкивались на препятствия, появились мышчные дрожания, опистотонус и при падении тоническо-клонические судороги и плавательные движения. Выявленные клинические признаки были схожи с проявлениями спонтанного заболевания телят СЦН. 


\section{References}

BENEVENGA, N. J. - BALDWIN, R. L. - RONNING, M.: Thiamine deficiency in dairy calves. J. Dairy Sci., 47, 1964: 702 p.

BESSEY, O. A. - LOWRY, O. H. - BROCK, M. J.: The quantitative determination of ascorbic acid in small amounts of white blood cells and platelets. J. biol. Chem., 168, 1947: 197-199.

BRIN, M.: Transketolase. In BERGMEYER, H. U.: Methods of enzymatic analysis. Vol. 2, New York and London, Verlag Chemie Weinheim, Academic Press, Inc., 1974: 703-709.

DRAPER, H. H. - JOHNSON, B. C.: Thiamine deficiency in the lamb. J. Nutr., 43, 194: 413422.

EDWIN, E. E. - MARKSON, L. M. - SHREEVE, J. - JACKMAN, R. - CARROLL, P. J.: Diagnostic aspects of cerebrocortical necrosis. Vet. Rec., 104, 1979: 4-8.

ESPINASSE, J. - REDON, P. - SINHA, R. P.: Reproduction experimentale de la necrose du cortex cerebral chez le mouton. Revue Méd. vét., 122, $1971: 529-545$.

FLACHOWSKY, G. - LÖHNERT, H. J. - HENNIG, A.: Einige Aspekte zur Vitamin-B -Versorgung von Lämmern nach provozierter Pansenazidose. Arch. Explt. Veterinärmed., 28, 1974 : $543-549$.

HAUGEN, H. N.: The determination of thiamine and thiamine phosphates in blood and tissues by the thiochrome method. Scand. J. clin. Lab. Invest., 13, 1961: 50-56.

JAGOS, P. - BOUDA, J. - DVORAK, V. - DVOŘAK, R. - HAMŠfK, V.: Studium aktivity enzymů, hladiny vitaminů a bílkovin $\mathrm{v}$ různých fázích ontogeneze $\mathrm{u}$ telat při metabolických poruchách. Project report Brno, University of Veterinary Science, 1978, $84 \mathrm{pp}$.

JAGOS, P. - VRZGULA, L. - HOFfREK, B.: Diagnostika a prevence chorob zviřat. II. Skot. Brno, Ediční středisko VŠV, 1979: $286 \mathrm{pp}$.

JAGOŚ, P. - BOUDA, J. - DVORAK, V. - PIVNfK, L. - MINKSOVÁ, E.: Studium klinických a klinicko-biochemických změn při spontánní a experimentálně vyvolané cerebrokortikální nekróze u telat. Veterinářství, 31, 1981: 149-152.

LILJA, C. G.: Cerebro-cortical necrosis (CCN) in calf an experimental reproduction of the disease. Acta vet. scand., 14, 1973: 464-473.

LITTLE, P. B: Biochemical and pathological studies of thiamine deficiency and polioencephalomalacia in cattle. Ph. D. Thesis, University of Minnesota USA, 1969.

LOEW, F. M. - DUNLOP, R. H.: Induction of thiamine inadequacy and polioencephalomalacia in adult sheep with Amprolium. Am. J. vet. Res., 33, 1972: 2195-2205.

MARKSON, L. M. - TERLECKI, S. - LEWIS, G.: Cerebrocortical necrosis in calves. Vet. Rec., 79, 1966: 578-579.

MARKSON, L. M. - LEWIS, G. - TERLECKI, S. - EDWIN, E. E. - FORD, J. E.: The etiology of cerebrocortical necrosis: the effects of administering antimetabolites of thiamine to preruminant calves. Br. vet. J., 128, 1972: 488-499.

MARKSON, L. E. - EDWIN, E. E. - LEWIS, G. - RICHARDSON, L.: The production of cerebrocortical necrosis in ruminant calves by the intraruminal administration of Amprolium. Br. vet. J., 130, 1974: 9-16.

MORGAN, K. T. - LAWSON, G. H. K.: Thiaminase type I - producing bacilli and ovine polioencephalomalacia. Vet. Rec., 95, 1974: 361-363.

PICKOVÁ, J.: Stanoveni thiaminu (vit. B ${ }_{1}$ ). CSN 560052.1969.

PILL, A. H. - DAVIES, E. T. - COLLINGS, D. F. - VENN, J. A. H.: The experimental reproduction of lesions of cerebrocortical necrosis in a calf. Vet. Rec., 78, 1966: 737-738.

PIVNfK, L.: Histopatologická identifikace syndromu tzv. cerebrokortikálních nekróz u telat v CSSR. Vet. Med., Praha, 17, 1972: 43-50.

SHARMA, S. K. - QUASTEL, J. H.: Transport and metabolism of thiamine in rat brain cortex in vitro. Biochem. J., 94, 1965: 790.

SHREEVE, J. E. - EDWIN, E. E.: Thiaminase-producing strains of Clostridium sporogenes associated with outbreaks of cerebrocortical necrosis. Vet. Rec., 94, 1974: 330.

TERLECKI, S. - MARKSON, L. M.: Cerebrocortical necrosis in cattle and sheep. Vet. Rec., 73, 1961: 32-27.

THOMPSON, J. N. - ERDODY, P. - BRIEN, R. - MURRAY, T. K.: Fluorometric determination of vitamin $A$ in human blood and liver. Biochem. med., 5, 1971: 67-89.

THOMPSON, J. N. - ERDODY, P. - MAXWELL, W. B.: Simultaneous fluorometric determinations of vitamins $A$ and $E$ in human serum and plasma. Biochem. med., 8, 1973:403-414.

ZINTZEN, H.: Vitamin $B_{1}$ (Thiamin) in der Ernährung des Wiederkäuers. Úbers. Tierernährg., 1, 1973: $273-323$. 